\title{
Influence of physical attributes on the price of land: the case of the Province of Talca, Chile
}

\author{
Javier L. Troncoso', Medardo Aguirre², Paula Manriquez¹, Varinia Labarra ${ }^{3}$, \\ Yony Ormazábal ${ }^{4}$ \\ 'Departamento de Economía Agraria, Universidad de Talca. Casilla 747, Talca, Chile. \\ ${ }^{2}$ Escuela de Ingeniería Comercial, Universidad de Talca. \\ ${ }^{3}$ Escuela de Agronomía, Universidad de Talca. \\ ${ }^{4}$ Centro de Geomática, Universidad de Talca.
}

\begin{abstract}
J.L. Troncoso, M. Aguirre, P. Manríquez, V. Labarra, and Y. Ormazábal. 2010. The influence of physical attributes on the price of land: the case of the province of Talca, Chile. Cien. Inv. Agr. 37(3): 105-112. This study aims at estimating the percent impact on the price of farmland of the following physical attributes: size, soil quality, water rights, connectivity and location. To this effect, all the farm sales occurred in the province of Talca between 2003 and 2006 were examined, directly from the corresponding title deeds, at the Conservador de Bienes Raíces (Property Register) of Talca, obtaining thus a total of 92 observations. Subsequently, a linear function was estimated, with price per hectare as the dependent variable and the physical attributes listed above, as explanatory variables. Analysis showed that the most influential variable is location (i.e. county) and in a very minor degree, connectivity (i.e. distance to the nearest paved road), water rights, soil quality and size. Talca is the preferred county, as location in other counties has negative impacts on price. Size and connectivity have negative impacts, while water rights and soil quality have positive impacts on price.
\end{abstract}

Key words: Hedonic price functions; marginal price; percent impact on price.

\section{Introduction}

When a farm is put up for sale, the owner usually describes it by its physical attributes. Thus, a complete soil map is normally provided, with a list of the different soil types present in the farm and their physical and chemical properties. Also,

Received September 30, 2009. Accepted October 5, 2009. Corresponding author: jtronc@utalca.cl the description would include water and energy sources and supply, connectivity, location, and similar physical characteristics. The relevance of this information is that it enables prospective buyers to define expectations about the rent generation capacity of the farm. The price of land is conditioned to these expectations, and it can be conceptualized as the present value $\mathrm{V}$ of a perpetual flow of (real) net revenues, $R_{t}$ :

$\mathrm{V}=\sum_{\mathrm{t}} \mathrm{R}_{\mathrm{t}} /(1+\mathrm{i})^{\mathrm{t}}$ 
where $\mathrm{i}$ is the real discount rate for year $\mathrm{t}(\mathrm{t}=0 \ldots \infty)$. In general terms, net revenue is the difference between the market value of all the goods and services provided by the land and the factors employed to obtain such goods and services, i.e. it is a measure of the land's capacity to add value (Alston, 1986: Burt, 1986; Robison et al., 1985).

Several studies have focused on the influence of net revenues on land prices. Burt (1986) modeled land prices as a function of farmland rents, assuming that farmland prices are best explained by the changes in net farm returns capitalized over time by the formula shown above. This author explored also the effect of inflation on land prices, concluding that its influence is of little significance. Alston (1986) analyzed the influence of expected net revenues and inflation on the increase observed in land prices between 1960 and 1980, in eight mid-western states. Similar to Burt (1986), he concluded that inflation had no effect and that the evolution of prices in the period mentioned could be explained essentially by the expected rents of agriculture in real terms. Robison et al. (1985) concluded that cash rents are the primary determinants of land prices, but suggested that nonagricultural demand for land also plays an important role.

Hedonic models have been used to estimate the marginal contribution of various land characteristics to price. Palmquist (1989) explained the rental price of land by the characteristics of the soil. Torell et al. (1990) used the capitalization formula specified above in a hedonic model to quantify differences in non-irrigated and irrigated farmland prices, in the U.S. Ogallala Aquifer region. Gracia et al. (2004) related the price of land in Zaragoza (Spain) to various socioeconomic and soil-quality variables, reaching the conclusion that, although both groups have an influence on price, soilquality and water availability are the most significant variables. Donoso and Vicente (2001) studied the influence of rental arrangements, soil physical characteristics (slope, depth, fertility) and farming practices (weed control, number of cultural operations) on the rental price of land in Tandil (Argentina). These au- thors found that rental arrangements, farming practices and slope were the most influential variables on the rental price. Nivens et al. (2002) included a measure of soil quality in a hedonic model of Kansas farmland values. Faux and Perry (1999) used a hedonic model of agricultural land sales to quantify the implicit market price of irrigation water. The inclusion of a measure of soil quality was an important element of their model. Sandry et al. (1982) used a hedonic model to determine the impacts of agricultural production, average farm size, irrigation, population, and urbanization on Oregon farmland prices. Barnard et al. (1997) followed a similar approach and included direct government payments when considering impacts of government programs on farmland prices.

Fuentes and Bravo-Ureta (2004) used a hedonic model to determine the most influential variables on farmland prices. The study was based on 552 farm valuations carried out in different regions of Chile, in the period 1981 to 1996. These authors concluded that infrastructure, proportion of irrigated land and soil quality have positive effects on land prices while the opposite occurs with size and distance to roads or cities.

Other studies have considered the impact of various government policies on land values. Taylor and Brester (2005) analyzed the effect of U.S. Government sugar price support policies on the value of the lands of Montana, a sugar beet producing state. They specified a model that included the rent generating capacity of the land, as well as variables representing soil quality, location, population density and parcel size. The results showed that the noncash income transfers generated by the U.S. sugar program have been capitalized into the Montana land prices.

This study aims at estimating the marginal contribution to price (i.e. marginal prices) of a number of physical attributes of land. The attributes are: total area, farm size, soil quality, water availability, connectivity and location. The study concentrates in the province of Talca, Chile. 


\section{Materials and methods}

\section{The data}

All the farm sales that occurred in the province of Talca between 2003 and 2006 were examined, directly from the corresponding title deeds, at the Conservador de Bienes Raíces (Property Register) of Talca. A total of 92 farms were sold in the period mentioned. The data compiled at the Conservador included: date of sale, total price, total area of the farm, water rights and county of location. These data were subsequently checked by examining the corresponding sale bills at the Archivo Judicial (Judiciary Archives) of Talca. Finally, soil use capacity and distance to paved road for each farm was obtained by directly measuring these attributes in the database of the Centro de Geomática (Geomatics Centre), using the software ArcGIS. Monetary values were expressed in constant Chilean pesos of June 2008, using the Consumer Price Index as deflator.

The variables obtained for each observation were the following:

- Price per hectare, in Chilean pesos of June 2008;

- Size of the farm, in hectares;

- Soil quality, measured as the proportion of soils Class I and II of use capacity in the total area (percentage);

- Water rights, in litres/second.

- Connectivity, measured in distance to the nearest paved road (kilometres);

- County where the farm is located. The following counties appeared in the sample of farms: Talca, Pelarco, San Rafael, Maule, Río Claro, Pencahue and San Clemente.

All variables are continuous, with the exception of counties which are binary.

\section{The model}

The determination of market values based on commodity attributes was carried out through the estimation of a hedonic price function. A 'hedonic price function' relates the price of a commodity to its various attributes or characteristics. The theoretical foundations of hedonic price functions were provided by Rosen (1974), who posited that competitive markets define implicit prices for the embodied commodity attributes, and that buyers evaluate these attributes when making a purchase decision.

Following the general hedonic functions model, it was assumed that the price of the i-th hectare of land $\mathrm{P}_{\mathrm{i}}$, is a function of the value attached by the economic agents to its attributes $Z_{\mathrm{ij}}(\mathrm{j}=1 \ldots \mathrm{m})$. Thus,

$P_{i}=f\left(Z_{i 1}, Z_{i 2}, \ldots . Z_{i j}, \ldots . . Z_{\text {im }}\right)$

It is also assumed that the market is in equilibrium, that is, that all buyers have made their utility-maximizing choices, given their budget constraints and knowledge of the prices and characteristics of alternative goods. Moreover, all firms have made their profitmaximizing decisions taking into account their production costs, and that the resulting prices and quantities have been set at marketclearing levels.

Initially ordinary least squares (OLS) analysis was employed for estimation, using a linear specification. However, the model showed non-normality of residuals, breaking thus one of the basic assumptions of the linear regression model and barring out the application of the usual parameter tests. Further analysis showed that non-normality of residuals was provoked by a non-normal price distribution. To overcome this difficulty, a truncated normal distribution of prices was assumed and a generalized linear model was adopted (Mc Cullagh and Nelder, 1989; Greene, 1999). Estimation was carried out by the maximum-likelihood method, ensuring thus asymptotical efficiency and asymptotical normality of the estimators. In summary, the following price function was estimated:

$$
P=\beta_{0}+\Sigma_{j} \beta_{j} Z_{j}+\sum_{w} \beta_{w} Z_{w}
$$

where $\mathrm{P}$ is the per-hectare price and $\mathrm{Z}_{\mathrm{j}}$ and $\mathrm{Z}_{\mathrm{w}}$ represent the $j$-th continuous variable and the w-th binary variable respectively. 
To avoid collinearity between the binary variables (the so-called 'dummy variable trap'), a reference variable was omitted in the group of counties. This was the county of Talca. Hence, results should be interpreted as departures, in pesos, from the price of a hectare in the county of Talca. This price is used as "reference price" (RP).

A linear specification implies constant marginal effects, an assumption which frequently does not hold in economics, where diminishing marginal effects are normally expected. In this particular case, however, being farmland prices expressed on a per-hectare basis, it seems realistic to hypothesize that the marginal effect of the different variables is close to constant, when averaged out by size. Moreover, in the case of the binary variables (e.g. county of location), only a constant marginal contribution to price seems logical, because of their one-orzero structure.

The marginal prices were estimated as the perunit contribution to price of each attribute, in pesos. Thus, the marginal prices of the $Z_{j}$ and $Z_{w}$ variables are $\beta_{j}$ and $\beta_{w}$ of equation (1), respectively. For the sake of comparison, these prices were expressed also as percentages of the reference price, a parameter that in the literature is termed "percent impact" (PI). Thus, the PI's were calculated as:

$\mathrm{PI}_{\mathrm{i}}=\beta_{\mathrm{i}}^{*} 100 / \mathrm{RP}$

$\mathrm{PI}_{\mathrm{w}}=\beta_{\mathrm{w}} * 100 / \mathrm{RP}$

\section{Results and discussion}

Summary statistics of the analyzed sample

Table 1 shows the distribution of the 92 farm sales that provided the data for this study. It can be observed that sales are concentrated in the counties of San Clemente, Pelarco and Rio Claro, which account for $72 \%$ of all sales reported during the analyzed period. However, a reasonable coverage of the Province of Talca is provided, as seven of a total of 10 counties are represented in the sample.
Table 1. Sales of farms in the period 2003-06 in the Province of Talca.

\begin{tabular}{lcc}
\hline County & $\begin{array}{c}\text { Number of } \\
\text { observations }\end{array}$ & $\%$ \\
\hline Talca & 6 & 7 \\
San Clemente & 36 & 39 \\
Río Claro & 12 & 13 \\
Pencahue & 5 & 5 \\
Maule & 6 & 7 \\
Pelarco & 18 & 20 \\
San Rafael & 9 & 10 \\
Total & 92 & 100 \\
\hline
\end{tabular}

The predominant group belongs to the range 11 to 20 hectares and $72 \%$ of all sales were below 30 hectares. However, the sample contained a wide coverage of farm sizes, from small parcels below 10 hectares up to farms above 60 hectares. Within the 12 farms of the range "above 60 hectares" there is a subgroup of 6 farms of more than 100 hectares of area. The largest farm had 498 hectares and the smallest, 6 hectares, i.e. the estimation domain for size is comprised between these limits.

Table 2. Size range of the sample of the group of farms under study.

\begin{tabular}{lcc}
\hline $\begin{array}{l}\text { Total area } \\
\text { (hectares) }\end{array}$ & $\begin{array}{c}\text { Number of } \\
\text { observations }\end{array}$ & $\%$ \\
\hline $1<$ Size $\leq 10$ & 16 & 17 \\
$10<$ Size $\leq 20$ & 38 & 41 \\
$20<$ Size $\leq 30$ & 13 & 14 \\
$30<$ Size $\leq 40$ & 5 & 5 \\
$40<$ Size $\leq 50$ & 5 & 5 \\
$50<$ Size $\leq 60$ & 3 & 3 \\
Size $>60$ & 12 & 13 \\
Total & 92 & 100 \\
\hline
\end{tabular}

Normally, water rights are proportional to the size of the farms that possess them. Hence, because the majority of the farms in the sample correspond to small holdings, $55 \%$ of the water rights fall in the range of 10 or less litres per second, and $73 \%$ in the range of 20 or less litres per second. However, the sample contained an ample array of water rights, going from nil (i.e. 
no irrigation) to 308 litres per second. This is the estimation domain for this variable.

Table 3. Water rights of the group of farms under study.

\begin{tabular}{lcc}
\hline $\begin{array}{l}\text { Water rights } \\
\text { (litres/second) }\end{array}$ & $\begin{array}{c}\text { Number of } \\
\text { observations }\end{array}$ & $\%$ \\
\hline $0<$ Water $\leq 10$ & 51 & 55 \\
$10<$ Water $\leq 20$ & 17 & 18 \\
$20<$ Water $\leq 30$ & 9 & 10 \\
$30<$ Water $\leq 40$ & 9 & 10 \\
Water $>40$ & 6 & 7 \\
Total & 92 & 100 \\
\hline
\end{tabular}

The connectivity of the farms sampled ranges from less than 1 kilometre to less than 11 kilometres, of distance to the nearest paved road. Hence, these are the limits of the estimation domain for this variable. Note that $77 \%$ are 6 or less kilometres distant to a paved road, which, for the Chilean conditions, can be considered as a fairly good connectivity.

Table 4. Distance to paved roads of the group of farms under study.

\begin{tabular}{lcc}
\hline $\begin{array}{l}\text { Distance } \\
\text { (kilometres) }\end{array}$ & $\begin{array}{c}\text { Number of } \\
\text { observations }\end{array}$ & $\%$ \\
\hline $0<$ Distance $\leq 1$ & 8 & 9 \\
$1<$ Distance $\leq 2$ & 16 & 17 \\
$2<$ Distance $\leq 3$ & 14 & 15 \\
$3<$ Distance $\leq 4$ & 8 & 9 \\
$4<$ Distance $\leq 5$ & 11 & 12 \\
$5<$ Distance $\leq 6$ & 14 & 15 \\
$6<$ Distance $\leq 7$ & 8 & 9 \\
$7<$ Distance $\leq 8$ & 6 & 7 \\
$8<$ Distance $\leq 9$ & 3 & 3 \\
$9<$ Distance $\leq 10$ & 2 & 2 \\
$10<$ Distance $\leq 11$ & 2 & 2 \\
Total & 92 & 100 \\
\hline
\end{tabular}

Soil quality, measured by the proportion of soils Class I and II, shows a bi-modal distribution, with modes in the extremes. Thus, low-quality (i.e. $0 \%$ Class I and II) and high-quality (i.e. 100\% Class I and II) soils are represented by 41 and $21 \%$ of the cases, respectively. As soil quality is one of the main determinants of farmland prices, the high proportion of low-quality soils explains why this sample showed a non-normal price dis- tribution, with a strong bias towards low prices. It should be noted that the high-quality soils are predominantly present in the county of San Clemente and, to a minor extent, in Rio Claro. The remaining counties include farms with soils of lower use capacity, above Class III, which puts them in a restricted cropping category, or definitely as grazing and forestry lands.

Table 5. Proportion of high-quality soils of the group of farms under study.

\begin{tabular}{lcc}
\hline $\begin{array}{l}\text { Proportion of } \\
\text { Class I and II soils } \\
(\%)\end{array}$ & $\begin{array}{c}\text { Number of } \\
\text { observations }\end{array}$ & $\%$ \\
\hline 0 & 41 & 51 \\
$0<$ Prop $\leq 10$ & 4 & 4 \\
$10<$ Prop $\leq 20$ & 6 & 7 \\
$20<$ Prop $\leq 30$ & 3 & 3 \\
$30<$ Prop $\leq 40$ & 1 & 1 \\
$40<$ Prop $\leq 50$ & 5 & 5 \\
$50<$ Prop $\leq 60$ & 0 & 0 \\
$60<$ Prop $\leq 70$ & 1 & 1 \\
$70<$ Prop $\leq 80$ & 2 & 2 \\
$80<$ Prop $\leq 90$ & 4 & 4 \\
$90<$ Prop $\leq 100$ & 19 & 21 \\
Total & 92 & 100 \\
\hline
\end{tabular}

\section{The price hedonic function}

Table 6 presents the maximum-likelihood estimates for the linear hedonic price function of farmland in the Province of Talca. The log likelihood function yields a likelihood ratio test in the rejection area at the $1 \%$ probability level $^{1}$ and supporting the conclusion that some or all the parameters of the price function are statistically different from zero. On closer examination, the

1 The overall goodness-of-fit test applicable to maximum-likelihood estimates is the likelihood ratio test, which follows a chi-square distribution and can be estimated as $\chi 20=2 *(\log$ likelihood function). The null hypothesis is that all the parameters equal zero. In this case $\chi 20=2 * 1,412.197=2,824.394$ which is far beyond $\chi 2.99(10$ d.f. $)=18.3$, allowing the rejection of the null hypothesis. 
t-ratios show that, with the exception of the estimate for the county of Pencahue, all coefficients are significant at the $1 \%$ or $5 \%$ probability levels.

\section{Farmland marginal prices}

As stated earlier, because the function is linear, the coefficients are direct estimates of the marginal prices of each variable or attribute. The analysis concentrates now on these prices and the corresponding percent impacts.

The "size" and "distance to paved roads" coefficients have negative signs, indicating that the price per hectare diminishes as the total area or distance to roads increases. These results are in line with the findings of Fuentes and BravoUreta (2004) in an earlier study, and agree with logic. Thus, the chance of including soils of different qualities is higher in large farms than in smaller ones, and this variability is recognized by the market in a smaller per-hectare price. Also, distant farms have difficulties in accessing the input and output markets, especially in relation to the labour forcé, so bad connectivity is punished by the market at the margin.

All counties also show negative signs, indicating that the land in the county of Talca is preferred to every other location. This result suggests that the market prefers those parcels of land close to a large city, where non-farm profits can be ob- tained from a future real estate development. Indeed, semi-urban parcels are common in the surroundings of Talca, a fact which does not occur in the more rural counties studied.

Water rights availability and the proportion of Class I and II soils have positive signs, indicating that both variables add value to the price of land, as was to be expected.

Table 7. Marginal prices and percent impact.

\begin{tabular}{lcc}
\hline Attribute (unit) & $\begin{array}{c}\text { Marginal price } \\
\text { (\$/unit) }\end{array}$ & $\begin{array}{c}\text { Percent impact } \\
(\%)\end{array}$ \\
\hline Size (hectares) & $-11,146.80$ & -0.17 \\
$\begin{array}{l}\text { Water rights (litres/ } \\
\text { second) }\end{array}$ & $16,846.90$ & 0.26 \\
$\begin{array}{l}\text { Distance to paved } \\
\text { roads (km) }\end{array}$ & $-174,737.00$ & -2.74 \\
Proportion of Class & $1,199,780.00$ & 18.84 \\
I and II soils (\%) & $-2,233,500.00$ & -35.06 \\
San Clemente & $-4,658,210.00$ & -73.13 \\
Rio Claro & $-861,841.00$ & -13.53 \\
Pencahue & $-3,643,830.00$ & -57.20 \\
Maule & $-4,318,890.00$ & -67.80 \\
Pelarco & $-3,823,460.00$ & -60.02 \\
San Rafael &
\end{tabular}

Reference price $=\$ 6,369,783$ per hectare.

The percent impact shows the weight of each variable on farmland prices. Table 7 shows that, in order of priority, the most influential variable

Table 6. Hedonic linear price function of farmland in the Province of Talca.

\begin{tabular}{lcccc}
\hline & Coefficient & Std. Error & t-ratio & Significance \\
\hline Constant & $6,029,350.00$ & $778,897.00$ & 7.74 & $* * *$ \\
Size (hectares) & $-11,146.80$ & $5,576.27$ & -2.00 & $* *$ \\
Water rights (litres/sec) & $16,846.90$ & $6,793.47$ & 2.48 & $* * *$ \\
Distance to paved roads (km) & $-174,737.00$ & $81,440.50$ & -2.15 & $* *$ \\
Proportion of Class I and II soils & $1,199,780.00$ & $470,181.00$ & 2.55 & $* * *$ \\
San Clemente & $-2,233,500.00$ & $671,444.00$ & -3.33 & $* * *$ \\
Rio Claro & $-4,658,210.00$ & $891,203.00$ & -5.23 & $* * *$ \\
Pencahue & $-861,841.00$ & $1,145,310.00$ & -0.75 & n.s. \\
Maule & $-3,643,830.00$ & $995,359.00$ & -3.66 & $* *$ \\
Pelarco & $-4,318,890.00$ & $864,514.00$ & -5.00 & $* * *$ \\
San Rafael & $-3,823,460.00$ & $916,133.00$ & -4.17 & $* * *$ \\
\hline
\end{tabular}

Number of observations: 92. Log likelihood function: $-1,412.197$.

Significance: *** Significant at a $1 \%$ probability level; ** Significant at a 5\% probability level; * Sgnificant at a $10 \%$ probability level; n.s.: Not significant. 
is location (i.e. counties). The most attractive location is the county of Talca, as the remaining counties subtract value to the reference price. All counties have double-digit (negative) impacts, although the impact of Pencahue should be considered nil, as its coefficient is not significant. The least attractive county is Rio Claro and the most attractive, besides Talca, is Pencahue.

The quality of the land, measured by the proportion of Class I and II soils, also exhibits a two-digit impact and is the second attribute in importance. This result proves that land is valued according to its fertility, a proxy to rentgenerating capacity, which stands to economic logic and is in line with the findings of all the authors cited above, especially Palquist (1989), Gracia et al. (2004) and Fuentes and Bravo-Ureta (2004). Each additional percent point adds $18.8 \%$ or $\$ 1,199,780$ to the price of the hectare.

Distance to paved roads is a variable of little impact, as it diminishes the value of the hectare by only $2.7 \%$ or $\$ 174,737$ per additional kilometre. However, the sign of the effect is correct and in line with the findings of Fuentes and Bravo-Ureta (2004).

Water rights and size appear of little impact, especially the latter whose impact is almost negligible. The little influence of water rights availability is surprising, as irrigation has been named by other studies as an influential determinant of the price of land. One possible explanation could be found in that the Chilean legislation does not tie up the water rights to the ownership of land, which implies that it is always possible to buy water in the secondary market. However, in this study water rights have less influence than that suggested by the literature and further research is in order.

\section{Conclusions}

This study proves that land attributes determine the price of land, as economic logic indicates. Although the data allowed the study of a limited number of attributes, it can be stated that the following have a decisive bearing on price: location, land quality, distance to paved roads, water rights availability and size.

The most influential attribute in the price of land is location (i.e. county) of the farm. In the case of the Province of Talca, the counties of Talca and Pencahue are preferred to all other counties. Probably this is related to eventual real estate earnings, as these counties are close to the city of Talca and semi-rural homes in halfhectare sites have become increasingly popular in central Chile. The quality of the land is the second most influential attribute, showing that land is generally valued as an agricultural resource. Finally, distance to paved roads, water rights availability and size have lower impacts on price. The relationship between water rights and the price of land requires further research, as the result of this study contradicts previous studies.

\section{Resumen}

J.L. Troncoso, M. Aguirre, P. Manríquez, V. Labarra y Y. Ormazábal. 2010. La influencia de los atributos físicos de la tierra en su precio: el caso de la Provincia de Talca, Chile. Cien. Inv. Agr. 37(3): 105-112. El objetivo general de este estudio fue estimar el impacto en el precio de la tierra de los siguientes atributos físicos: tamaño del predio, comuna, distancia a camino pavimentado, cantidad de agua disponible y calidad de los suelos. Para alcanzar los objetivos señalados se acudió al Conservador de Bienes Raíces y al Archivo Judicial de Talca, donde se analizaron las transacciones de tierra ocurridas en la provincia entre 2003 y 2006, las que totalizan 92 casos. Se ajustó una función lineal con el precio como variable dependiente y los atributos ya indicados, como variables independientes. Las conclusiones del estudio fueron las siguientes: La variable más influyentes en el precio de la tierra es la comuna y, en mucho 
menor grado, la distancia a camino pavimentado, cantidad de agua, superficie total y calidad de suelos. Todas las comunas distintas de Talca tienen impactos negativos sobre el precio, lo que sugiere que los predios de la comuna de Talca son preferidos a los de otras comunas. El tamaño del predio y la distancia a camino pavimentado tienen un impacto negativo sobre el precio por hectárea. La cantidad de agua de riego y la calidad de suelos impactan positivamente sobre el precio.

Palabras claves: Función hedónica de precios; precio marginal; impacto porcentual en el precio.

\section{References}

Alston, J.M. 1986. An analysis of growth of U.S. farmland prices, 1963-82. Amer. J. Agr. Econ. 68:1-9.

Barnard, C.H., G. Whittaker, D. Westenbarger, and M. Ahearn. 1997. Evidence of capitalization of direct government payments into U.S. cropland values. Amer. J. Agr. Econ. 79:1642-50.

Burt, O. 1986. Econometric modeling of the capitalization formula for farmland prices. Amer. J. Agr. Econ. 68:10-26.

Donoso, G., and G. Vicente. 2001. Caracterización hedónica de los precios de la tierra agrícola en la región pampeana, Argentina. Cien. Inv. Agr. 28(2): 73-81.

Faux, J., and G.M. Perry. 1999. Estimating irrigation water value using hedonic price analysis: A case study in Malheur County, Oregon. Land Econ. 75 (August):440-52.

Fuentes, P., and B. Bravo-Ureta. 2004. Determinantes del valor de la tierra agrícola en Chile: Un enfoque hedónico. Proceedings of the VIII Congress of the Chilean Association of Agricultural Economists, Facultad de Agronomía, Pontificia Universidad Católica de Chile (Editors), Santiago.

Gracia, A., L. Perez y Perez, A. Sanjuan, and J. Barreiro Hurle. 2004. Análisis hedónico de los precios de la tierra en la provincia de Zaragoza. Estudios Agrosociales y Pesqueros 202:51-69.
Greene, W.H. 1999. Análisis econométrico. Third Edition. Prentice Hall, Madrid, España. 913 pp.

Mc Cullagh,P., and F. Nelder. 1989. Generalized linear models. Second edition, Chapman and Hall. London, UK. 511 pp.

Nivens, H.D., T.L. Kastens, K.C. Dhuyvetter, and A.M. Featherstone. 2002. Using satellite imagery in predicting Kansas farmland values. J. Agr. Resour. Econ. 27 (December 2002):464480.

Palmquist, R.B. 1989. Land as a differential factor of production: A hedonic model and its implications for welfare measurements. Land Econ. 65 (February):23-28.

Sandry, R.A., L.M. Arthur, R.A. Oliveira, and W.R.Wilson. 1982. Determinants of Oregon farmland values: A Pooled Cross-Sectional, Time Series Analysis.” W. J. Agr. Econ. 7(December):211-220.

Robison, L.J., D.A. Lins, and R. VenKataraman. 1985. Cash rents and land values in U.S. Agriculture.Amer. J. Agr. Econ. 67 (November):794-805.

Rosen, S. 1974. Hedonic prices and implicit markets: product differentiation in pure competition. Journal Political Economy 82: 34-55.

Taylor, M.R. and Brester, G.W. 2005. Noncash income transfers and agricultural land values. Rev. Agric. Econ. 27(4): 526-541.

Torell, L.A., J.D. Libbin, and M.D. Miller, 1990. The market value of water in the Ogallala aquifer. Land Econ. 66:163-75. 